two generations, it brings the present case into line with other exceptions to the normal life-history cycle, whose bearing on the nature of alternation has been discussed by Bower ${ }^{1}$. The present case, although more striking in its appearance, seems, so far as it has been investigated, to afford no sufficient reason for dissenting from the conclusion at which he arrived.

It is of interest to note the additional evidence, were such needed, which these observations afford of the generalization made by Goebel ${ }^{2}$, that the sporangium is to be regarded as an organ suigeneris.

From the staff of the Royal Gardens, Kew, I received ready assistance in many practical matters in the conduct of the cultures; my thanks are especially due to the curators, Mr. Watson and Mr. Nicholson.

ON CHEIROSTROBUS, A NEW TYPE OF FOSSIL CONE FROM THE CALCIFEROU SANDSTONES ${ }^{3}$. By D. H. ScotT, M.A., Ph.D., F.R.S.-The Peduncle.-The first indication of the existence of the remarkable type of fructification about to be described, was afforded by the study of a specimen in the Williamson collection, from the well-known fossiliferous deposit at Pettycur, near Burntisland, belonging to the Calciferous Sandstone Series at the base of the Carboniferous formation. This specimen is a fragment of stem, of which seven sections are preserved in the collection ${ }^{4}$. Its discoverer thought it might possibly belong to the Lepidostrobus found in the same bed. 'If so,' he adds, 'it has been part of the axis of a somewhat larger strobilus than those described ${ }^{5}$ '.

A detailed examination of the structure of this specimen convinced me that it is essentially different from any Lepidodendroid axis, and is, certainly, a new type of stem ${ }^{6}$.

As it was the examination of this fragment of stem which first put me on to the track of the new cone, it may be well shortly to describe its chief characteristics, reserving all details for a future paper.

1 Annals of Botany, Vol. iv, I 890, p. 347.

${ }^{2}$ Bot. Zeit., I881, p. 707.

${ }^{3}$ Preliminary Paper, read before the Royal Society, January 21, I897.

4 The cabinet-numbers are $539-545$.

5 Williamson, Organization of the Fossil Plants of the Coal-measures. Part III. Phil. Trans., I 872 , p. 267 .

${ }^{6}$ A short account of this specimen was given by me before the Botanical Section of the British Association at the Liverpool Meeting, I 896. See Brit. Assoc. Report, 1896 . 
The specimen, which is about $7 \mathrm{~mm}$. in diameter, bears the bases only of somewhat crowded leaves, the arrangement of which, though not quite clear, was most probably verticillate, with from nine to twelve leaves in a whorl, those of successive whorls being superposed. Each leaf-base consists of a superior and an inferior lobe, and each lobe is palmately subdivided into two or three segments.

The leaf-traces, which are single bundles where they leave the central cylinder, subdivide in both planes on their way through the cortex to supply the lobes and segments of the leaf.

The central cylinder is polyarch, the strand of wood having from nine to twelve prominent angles, with phloem occupying the furrows between them. With the exception of the spiral protoxylem-elements at the angles, the tracheae have multiseriate bordered pits, thus differing conspicuously from the scalariform tracheae of the Lepidodendreae. The interior of the stele is occupied by tracheae intermingled with conjunctive parenchyma. There is a well-marked formation of secondary tissues by means of a normal cambium ${ }^{1}$.

\section{The Strobilus.}

Mr. R. Kidston, F.G.S., kindly informed me that he had in his possession sections of a fossil cone from Burntisland having certain points in common with the Williamson specimen. On inspecting these sections with Mr. Kidston, I was soon convinced that this undescribed cone really belonged to the same plant as the fragment of stem in the Williamson Collection, and that the latter might well be the peduncle of the former. At the same time I satisfied myself, and Mr. Kidston agreed with me, that the whole organization of his cone is fundamentally different from that of any Lepidostrobus, the decisive

1 The general structure of this axis, including the course of the bundles and the subdivision of the bracts, is correctly described by Williamson, loc. cit., p. 297. As regards the latter point, he says, " peripherally the bark breaks up into main or primary bracts, which again subdivide, as in the transverse section, into secondary ones, demonstrating that each primary bract does not merely dichotomize, but subdivides, both horizontally and vertically, into a cluster of bracts-a condition corresponding with what I have already observed in the smaller strobili described.' These smaller strobili are those of the Burntisland Lepidostrabus, to which, by a strange coincidence, Williamson, loc. cit., p. 295, erroneously attributed the same character, as regards subdivision of the bracts, which actually exists in the new cone. The only explanation appears to be that Williamson interpreted the structure of the Lepidostrobus in the light of that of the peduncle, which, as we shall see, really belonged to a totally different fructification. 
point being that the new cone has compound branched sporophylls, each of which bears a number of sporangia. It became evident that this cone must be placed in a new genus, and the conclusion arrived at from the study of the peduncle was thus confirmed.

Mr. Kidston most generously handed over his sections to me for examination and description, and also obtained for me from the owner the remains of the original block, from which I have had a number of additional sections prepared.

Only a single specimen of the cone is at present known. Before cutting sections, the piece, which includes the base but not the apex of the strobilus, was about two inches long. It was found at Pettycur, near Burntisland, in $\mathbf{1} 883$, by Mr. James Bennie, of Edinburgh. The specimen is calcified, and its preservation is remarkably perfect, so that the whole structure is well shown, though the complexity of its organization renders the interpretation in some respects difficult.

The cone in its present somewhat flattened condition measures about $5 \mathrm{~cm}$. by $2 \cdot 3 \mathrm{~cm}$. in diameter. The diameter in its natural state would have been at least $3.5 \mathrm{~cm}$. That of the axis is about $7 \mathrm{~mm}$., exactly the same as that of Williamson's peduncle. Thus the extreme length of the sporophylls, which have on the whole an approximately horizontal course, is about $\mathrm{I} \cdot 4 \mathrm{~cm}$.

The sporophylls are arranged in somewhat crowded verticils, fourteen of which were counted in a length of an inch, $2.5 \mathrm{~cm}$. There are twelve leaves in each whorl, and the members of successive whorls are accurately superposed, a fact which is shown with the greatest clearness in tangential sections of the cone. This is evidently a point of great significance in considering the affinities of the fossil.

The sporophylls themselves have a remarkably complex form. At its insertion on the axis each sporophyll consists of a short basal portion or phyllopodium; the bases of the sporophylls belonging to the same verticil are coherent. The sporophyll branches immediately above its base, dividing into a superior and an inferior lobe, which lie directly one above the other in the same radial plane. Almost at the same point each of the lobes subdivides in a palmate manner into three segments, which assume a horizontal course, whereas the common phyllopodium has an upward inclination. It is probable that sometimes, especially at the base of the cone, there may be two instead of three segments to each lobe. As a rule, however, each sporophyll consists of six segments, of which three belong to the 
superior (ventral or posterior) and three to the inferior (dorsal or anterior) lobe.

The segments are of two kinds-sterile and fertile. Both alike consist of a long, straight, slender pedicel, running out horizontally, and terminating at the distal end in a thick laminar expansion. The sterile segments are the longer, and their laminae bear, in each case, an upturned foliaceous scale as well as a shorter and stouter downward prolongation ${ }^{1}$.

Each of the fertile segments ends in a fleshy laminar enlargement not unlike the peltate scale of an Equisetum or a Calamostachys. These fertile laminae, which are protected on the exterior by the overlapping ends of the sterile segments, bear the sporangia. Four, perhaps in some cases five, sporangia are attached, by their ends remote from the axis, to the inner surface of the peltate fertile lamina. Each sporangium is connected with the lamina by a somewhat narrow neck of tissue into which a vascular bundle enters. The sporangia are of great length, and extend back along the pedicels until they nearly or quite reach the axis.

The sterile and fertile segments alternate regularly, one above the other, in the same vertical series. So much is evident, but the question, which segments are fertile and which sterile, has presented great difficulties, owing to the fact that the same segment can scarcely ever be traced continuously throughout the whole of its long course, and that the pedicels of sterile and fertile segments present no constant distinctive characters. For reasons, however, which will be fully given in a subsequent paper, I think it highly probable that in each sporophyll the segments of the lower lobe are sterile, and those of the upper lobe fertile, constituting the sporangiophores.

The sporangia and pedicels are all packed closely together so as to form a continuous mass. The external surface of the cone was completely protected by its double investiture of fertile and sterile laminae.

The spores are well preserved in various parts of the cone, and, so far as this specimen shows, are all of one kind, their average diameter. being $0.065 \mathrm{~mm}$. At the base of the cone, where macrospores, if they existed, might naturally be looked for, the spores are of the same size as elsewhere. So far, then, there is no evidence of heterospory.

\footnotetext{
${ }^{1}$ I now find that both the upturned scale and the downward prolongation are
} in reality double. D. H. S., February II, 1897 . 
The spores are considerably larger than the microspores of the Lepidostrobi. Those of the Burntisland Lepidostrobus, for example, are barely $0.02 \mathrm{~mm}$. in diameter. The spores of our plant approach in size those of Sphenophyllum Dawsoni, or the microspores of Calamostachys Casheana.

The sporangial wall, as preserved, is only one cell in thickness; it bears no resemblance to the palisade-like layer which forms the wall of the sporangium in Lepidostrobus, but has the same structure as that of a Calamostachys ${ }^{1}$. The sporangial wall of Sphenophyllum Dazesoni is similar.

The anatomy of the axis of the cone agrees closely with that of the peduncle above described, except for the absence of any secondary tissues. The wood has twelve prominent angles, at which the spiral tracheae are situated, so its development was, no doubt, centripetal. The inner tracheae have pitted walls, and are intermixed with scattered parenchymatous cells, imperfectly preserved. The phloem has entirely perished.

The most interesting anatomical feature is the course of the leaftrace bundles, which can be followed with the greatest exactness on comparing sections in the three directions.

A single vascular bundle starts from each angle of the stele for each sporophyll, and passes obliquely upwards. When less than halfway through the cortex, the trace divides into three bundles, one median and two lateral. The lateral strands are not always both given off exactly at the same point. A little further out the median bundle divides into two, which in this case lie in the same radial plane, so that one is anterior, and the other posterior. The median posterior bundle is the larger, and before leaving the cortex this, in its turn, divides into three. There are now six branches of the original leaf-trace, three anterior, and three posterior, which respectively supply the lower and upper lobes of the sporophyll. The three segments of the lower lobe are supplied by the two lateral bundles first given off, and by the anterior median bundle, while the upper segments receive the posterior median bundle and its two lateral branches. In the base of the sporophyll all six bundles can be

${ }^{1}$ See Weiss, Steinkohlen-Calamarien, Vol. ii, I884, Plate XXIV, Figs. 3, 4, and 5; Williamson and Scott, Further Observations on the Organization of the Fossil Plants of the Coal-measures, Part I, Phil. Trans., I894, Plate 8I, Fig. 3I. 
clearly seen, in tangential sections of the cone, three above and three below. As the segments become free, one bundle passes into each, and runs right through the pedicel to the lamina. In the fertile lamina the bundle subdivides, a branch diverging to the point of insertion of each sporangium.

One of the longitudinal sections passes through the base of the cone, so as to show part of the peduncle in connexion with it. In this peduncle secondary wood is present, just as in the separate specimen belonging to the Williamson Collection. Higher up in the axis of the cone, where the sporophylls begin to appear, the secondary wood dies out. This evidence materially confirms the conclusion that the Williamson peduncle really belongs to our strobilus.

\section{Diagnosis.}

It is evidently necessary to establish a new genus for the reception of this fossil; the generic name which I propose is Cheirostrobus, intended to suggest the palmate division of the sporophyll-lobes ( $\chi$ ei $\rho$, hand). The species may be appropriately named Pettycurensis, from the locality where the important deposit occurs which has yielded this strobilus and so many other valuable specimens of palaeozoic vegetation. The diagnosis may provisionally run as follows :-

Cheirostrobus, gen. nov.

Cone consisting of a cylindrical axis bearing numerous compound sporophylls, arranged in crowded many-membered verticils.

Sporophylls of successive verticils superposed.

Each sporophyll divided, nearly to its, base, into an inferior and a superior lobe; lobes palmately subdivided into long segments, of which some (probably the inferior) are sterile, and others (probably the superior) fertile, each segment consisting of an elongated stalk bearing a terminal lamina.

Laminae of sterile segments foliaceous; those of fertile segments (or sporangiophores) peltate.

Sporangia large, attached, by their ends remote from the axis, to the peltate laminae of the sporangiophores.

Sporangia on each sporangiophore, usually four.

Spores very numerous in each sporangium.

Wood of axis polyarch.

C. Pettycurensis, sp. nov. 
Cone, 3-4 $\mathrm{cm}$. in diameter, seated on a distinct peduncle. Sporophylls, twelve in each verticil.

Each sporophyll usually sexpartite, three segments belonging to the inferior, and three to the superior, lobe.

Sporangia densely crowded.

Spores about $0.065 \mathrm{~mm}$. in diameter.

Horizon: Calciferous Sandstone Series.

Locality: Pettycur, near Burntisland, Scotland. Found by Mr. James Bennie, of Edinburgh.

Both generic and specific characters are manifestly subject to alteration, if other similar fossils should be discovered. In the meantime the above diagnoses are given in order to facilitate identification.

\section{Affinities.}

Any full discussion of affinities must be reserved for the detailed memoir, which I hope to lay before the Royal Society in a short time. At present only a few suggestions will be offered.

The idea of a near relationship to Lepidostrobus-so specious at first sight-is negatived by accurate investigation. There may have been a certain resemblance in external habit, as there is in the naked-eye appearance of the sections, but this means nothing more than that the specimen is a large cone, with crowded sporophylls and radially elongated sporangia. The only real resemblance to Lepidostrobus is in the polyarch strand of primary wood, but even here the details, as, for example, the structure of the tracheae, do not agree. In other respects the differences from any Lepidodendroid fructification are as great as they can be.

I do not doubt that the genus with which Cheirostrobus has most in common is Sphenophyllum. The chief points of agreement are as follows :-

I. The superposed foliar whorls. This certainly agrees with the vegetative parts of Sphenophyllum, and, according to Count SolmsLaubach, the superposition holds good for the bracts of its strobili also ${ }^{1}$.

2. The deeply divided palmatifid sporophylls, agreeing with the leaves of various species of Sphenophyllum, e. g. S. tenerrimum.

3. The division of the sporophyll into a superior or ventral, and an inferior or dorsal, lobe, agreeing with the arrangement in

1 Bormanites Römeri, eine nene Sphenophylleen-Fructification, I895, p. $24^{2}$. 
Sphenophyllum Daresoni, or S. cuneifolium, according to M. Zeiller's interpretation ${ }^{1}$.

4. The differentiation of the sporophyll into sterile segments (bracts) and fertile segments (sporangiophores). The comparison with Sphenophyllum is much strengthened if, as I believe to be the case, the segments of the inferior lobe in Cheirostrobus are sterile, and those of the superior lobe fertile.

5. The repeated subdivision of the leaf-trace vascular bundles, in passing through the cortex of the axis ${ }^{2}$, as in Sphenophyllum Stephanense.

6. The attachment of the sporangia to a laminar expansion at the distal end of the sporangiophore. As regards this point, comparison should be made with the Boremanites Römeri of Count Solms-Laubach (loc. cit.).

7. The structure of the sporangial wall.

I think that the sum of these characters, to which others might be added, justifies the suggestion that Cheirostrobus may be provisionally placed in the same phylum, or main division, of Pteridophyta with Sphenophyllum, though indications of possible affinities in other directions are not wanting, and will be discussed on another occasion.

Cheirostrobus, even more than Sphenophyllum itself, appears to combine Calamarian with Lycopodiaceous characters, and might reasonably be regarded as a highly specialized representative of an ancient group of plants lying at the common base of these two series.

It appears likely that in Cheirostrobus one of those additional forms of Palaeozoic Cryptogams, allowing of comparison with Sphenophyllum, has actually been brought to light, the discovery of which Dr. Williamson and I ventured to anticipate at the close of our first joint memoir ${ }^{3}$.

NOTE ON THE DISCOVERY OF MYCORHIZA.-In the Botanische Zeitung for I886, Wahrlich gives (p. 48I) the early bibliographical history of Mycorhiza. He says, 'Schleiden war der

1 Étude sur la constitution de l'appareil fructificatif des Sphénophyllum. Mém. de la Soc. Géol. de France, Paléontologie, Mém. I I, I893, p. 37 .

${ }^{2}$ Cf. Renault, Cours de Botanique fossile, Vol. ii, Plate XIV, Fig. 2 ; Plate XV, Fig. 3, Vol. iv, p. I5.

${ }^{3}$ Williamson and Scott, Further Observations on the Organization of the Fossil Plants of the Coal-measures, Part I, Phil. Trans., 1894 B, p. 946. 


\section{$2 \mathrm{BHL}$ Biodiversity Heritage Library}

Scott, Dukinfield Henry. 1897. "On Cheirostrobus, a new type of fossil cone from the calciferous sandstones." Annals of botany 11, 168-175. https://doi.org/10.1093/oxfordjournals.aob.a088641.

View This Item Online: https://www.biodiversitylibrary.org/item/233542

DOI: https://doi.org/10.1093/oxfordjournals.aob.a088641

Permalink: https://www.biodiversitylibrary.org/partpdf/318458

\section{Holding Institution}

Smithsonian Libraries

\section{Sponsored by}

Biodiversity Heritage Library

\section{Copyright \& Reuse}

Copyright Status: Not in copyright. The BHL knows of no copyright restrictions on this item.

This document was created from content at the Biodiversity Heritage Library, the world's largest open access digital library for biodiversity literature and archives. Visit BHL at https://www.biodiversitylibrary.org. 